\section{Effects of Temperature and Salinity on the in vitro Proliferation of Trophozoites and the Development of Zoosporangia in Perkinsus olseni and $P$. honshuensis, Both Infecting Manila Clam}

\author{
Kousuke Umeda, Jun Shimokawa and \\ Tomoyoshi Yoshinaga*
}

Department of Aquatic Bioscience, Graduate School of Agricultural and Life Sciences, The University of Tokyo, Tokyo 113-8657, Japan

(Received October 9, 2012)

\begin{abstract}
We evaluated the effects of temperature and salinity on in vitro trophozoite proliferation and zoosporangial development in Perkinsus olseni and P. honshuensis, infecting Manila clam. Trophozoite proliferation was highest at $28^{\circ} \mathrm{C}$ for both species and at $18-21 \%$ and $21-33 \%$ for $P$. olseni and $P$. honshuensis, respectively. Zoospore release rates, as the indicator of zoosporulation, were highest at $25-30^{\circ} \mathrm{C}$ and $25-35 \%$ for both species. However, these results seem not to explain the previously observed phenomena, i.e. lower infection prevalence in estuarine tidal flats (the two species not distinguished) and higher infection prevalence of $P$. olseni than $P$. honshuensis.
\end{abstract}

Key words: Perkinsus olseni, Perkinsus honshuensis, temperature, salinity, Ruditapes philippinarum

In Japan, the annual harvest of Manila clam Ruditapes philippinarum has decreased significantly since the mid-1980s and remains low because of a concurrent decline in the abundance of wild Manila clam populations ${ }^{1)}$. Overfishing, degeneration of sediments, mass depletion of larvae, predators and some other factors have been suggested as the causes of the decline in population abundance ${ }^{1)}$. Although the exact causes remain unclear, infection with Perkinsus species has recently shown up as a major contributor to the depletion of Manila clam resources ${ }^{2,3}$. Perkinsus infections have been reported in Manila clams throughout Japan, including areas other than northern and eastern Hokkaido ${ }^{4,5)}$. The prevalence and intensity of infection with Perkinsus species varies considerably among different populations of Manila clams ${ }^{4,5)}$. Manila clams in

\footnotetext{
* Corresponding author

E-mail: atyoshi@mail.ecc.u-tokyo.ac.jp
}

Japan have been thought to be infected only with Perkinsus olseni. Recently, Dungan and Reece (2006) described a new species, $P$. honshuensis, in Manila clams collected from Mie Prefecture, Japan ${ }^{6}$. However, our prior research suggests that $P$. olseni is the dominant species infecting Manila clams in Japan ${ }^{7)}$.

The variation in infection levels among different Manila clam populations and between the two Perkinsus species suggests that environmental factors may affect Perkinsus infection in Manila clams. We evaluated whether temperature and salinity affected the proliferation of trophozoites and the development of zoosporangia in vitro in $P$. olseni and $P$. honshuensis.

\section{Materials and Methods}

\section{Manila clams}

We purchased uninfected Manila clams (shell length: 35-45 mm) from the Akkeshi Fisheries Cooperative Association. The clams were collected from the tidal flat at Akkeshi, Hokkaido, Japan, an area that is free of Perkinsus spp.

\section{Trophozoites and prezoosporangia}

We purchased trophozoites of $P$. olseni (PRA-181) and $P$. honshuensis (PRA-177) from the American Type Culture Collection (ATCC) and subcultured them in Perkinsus broth medium (PBM) (ATCC medium 1886), 745 mOsm (equivalent to the seawater at a salinity of $22 \%$ ), as follows. We added $1 \mathrm{~mL}$ of the old culture to $10 \mathrm{~mL}$ of fresh medium at 2-3 wk intervals and incubated the culture at $25^{\circ} \mathrm{C}$ in the dark.

Prezoosporangia were obtained by culturing the soft tissue of clams injected with the trophozoites. Two tiny holes were drilled in the anterior and posterior side of the shell of each uninfected clam. Through the holes, each adductor muscle was injected with $0.1 \mathrm{~mL}$ culture of trophozoites. The injected clams were held in a tank containing $40 \mathrm{~L}$ aerated seawater at $20^{\circ} \mathrm{C}$ for a week. The gill and mantle tissues of the clam (0.7-1.0 g) were homogenized, centrifuged at $300 \times g$ for $5 \mathrm{~min}$, and incubated individually in $20 \mathrm{~mL}$ Ray's fluid thioglycollate medium (RFTM), which is commonly used to develop Perkinsus trophozoites infecting host tissues into prezoosporangia ${ }^{8,9)}$, supplemented with antibiotics (500 IU/mL penicillin G potassium and $500 \mu \mathrm{g} / \mathrm{mL}$ streptomycin sulfate) at $25^{\circ} \mathrm{C}$ for $4 \mathrm{~d}$. After incubation, the media were removed by centrifuging (300 $\times g$ for $5 \mathrm{~min}$ ), and the clam tissue homogenates were digested in $0.25 \%$ trypsin solution in $20 \mathrm{~mL}$ filer-sterilized seawater (FSSW, 30\% salinity) for $90 \mathrm{~min}$ at $25^{\circ} \mathrm{C}$ to obtain prezoosporangia. After serial filtrations through 200 , 100 , and $50 \mu \mathrm{m}$ nylon meshes for $P$. olseni or 300,200 , and $50 \mu \mathrm{m}$ for $P$. honshuensis, the prezoosporangia trapped on the $50 \mu \mathrm{m}$ mesh were collected and washed twice with FSSW by centrifuging at $300 \times g$ for $5 \mathrm{~min}$. 
We used filter-sterilized artificial seawater (FASW, 30\%。 salinity) (Instant Ocean Sea Salt, Aquarium Systems) supplemented with antibiotics (200 IU/mL penicillin G potassium and $200 \mu \mathrm{g} / \mathrm{mL}$ streptomycin sulfate) for the production and incubation of prezoosporangia throughout the present study, unless otherwise stated.

Effect of temperature and salinity on trophozoite proliferation

Temperature. Cultures of $P$. olseni and $P$. honshuensis were filtered in a sterile environment through $10 \mu \mathrm{m}$ nylon mesh to remove aggregated trophozoites. The filtrates were centrifuged at $275 \times g$ for $5 \mathrm{~min}$ to remove the old culture medium. The pelleted cells were resuspended in fresh PBM to adjust the cell densities to $4.0 \times 10^{5}$ cells $/ \mathrm{mL}$ for $P$. olseni and to $2.0 \times 10^{5}$ cells $/ \mathrm{mL}$ for $P$. honshuensis. Cell densities were determined using a hemocyte counting chamber. We pipetted $100 \mu \mathrm{L}$ of each suspension into wells of each 96-well culture plate in triplicate and $100 \mu \mathrm{L}$ of PBM was used as a blank sample. The plates were individually placed in incubation moisture chambers and incubated at $16^{\circ} \mathrm{C}, 19^{\circ} \mathrm{C}, 22^{\circ} \mathrm{C}, 25^{\circ} \mathrm{C}, 28^{\circ} \mathrm{C}, 31^{\circ} \mathrm{C}$, $34^{\circ} \mathrm{C}$, or $37^{\circ} \mathrm{C}$. The number of cells in each well was quantified on day $0,2,3,4,5,6$, and 7 using a commercial cell proliferation assay kit [Cell Counting Kit-8 (CCK8), Dojindo Laboratories]. Identical trials were repeated twice using different bathes of cultures.

Salinity. We evaluated the effect of salinity by rearing $P$. olseni and $P$. honshuensis in culture media of different osmolalities of $300 \mathrm{mOsm}$ (9\%), $405 \mathrm{mOsm}$ (12\%०), 510 mOsm (15\%०), 605 mOsm (18\%०), 700 mOsm (21\%०), 890 mOsm (27\%॰), 1080 mOsm (33\%०), or 1270 mOsm (39\%) (the value in each parenthesis represents salinity equivalent to each osmolality). The osmolality was adjusted by varying the amount of artificial seawater salts in original PBM, and measured using a vapor pressure osmometer (Vapro Osmometer 5520, Wescor). Cultures of $P$. olseni and $P$. honshuensis were filtered through a $10 \mu \mathrm{m}$ nylon mesh to remove aggregated trophozoites. The cell densities of the filtrates were adjusted to $1.0 \times 10^{6} \mathrm{cells} / \mathrm{mL}$ for both species. The cell suspensions were dispensed into 3 $\mathrm{mL}$ aliquots and pelleted by centrifugation $(275 \times g$ for 5 $\mathrm{min}$ ) then resuspended in $3 \mathrm{~mL}$ fresh media at different osmolalities. We incubated the suspensions at $25^{\circ} \mathrm{C}$ in 96-well culture plates, and the cell densities were determined using CCK-8 at intervals similarly to the experiment for temperature-dependent proliferation. Identical trials were repeated twice using different batches of cultures.

Cell proliferation assay. Ten microliters of CCK-8 solution supplemented with antibiotics $(200 \mathrm{IU} / \mathrm{mL}$ of penicillin $\mathrm{G}$ potassium and $200 \mu \mathrm{g} / \mathrm{mL}$ of streptomycin sulfate) was added to the wells containing the cell suspensions. The plate was incubated for $3 \mathrm{~h}$ (temperature) or $2.5 \mathrm{~h}$ (osmolality) at $25^{\circ} \mathrm{C}$ in the dark to allow the reaction and colorization. The absorbance (ABS) of each well was read at $450 \mathrm{~nm}$ using a microplate reader (model MPR-A4, Tosoh). The incubation periods and temperature were optimized during preliminary experiments, and the ABS was proportional to the living cell number between $5.0 \times 10^{5}-1.0 \times 10^{7}$ cells $/ \mathrm{mL}$ (P. olseni) or $1.0 \times 10^{5}-5.0 \times 10^{6}$ cells $/ \mathrm{mL}$ ( $P$. honshuensis) for this assay, which corresponded to ABS $0.04-0.80$ or ABS 0.04-2.00, respectively.

Effects of temperature and salinity on development of zoosporangia

The release of zoospores from prezoosporangia can be an indicator of zoosporangial development. Therefore, we measured the effect of temperature and salinity on the rate of zoospore release. Zoospore release rates were arcsine-transformed, and then analyzed by Tukey-Kramer test.

Temperature. The prezoosporangia of the two Perkinsus species were incubated in FASW at $20^{\circ} \mathrm{C}$, $25^{\circ} \mathrm{C}, 30^{\circ} \mathrm{C}$, or $35^{\circ} \mathrm{C}$. Prezoosporangia (30-70 cells) were placed in $1 \mathrm{~mL}$ FASW in each well of 24-well plates. They were observed under an inverted microscope every day for a week. Zoosporangia that were releasing zoospores at the time of observation or those that had already completed releasing were counted to obtain zoospore release rates.

Salinity. Prezoosporangia (30-70 cells) were placed in $1 \mathrm{~mL}$ FASW with different salinities (10\%。, $15 \%$, $20 \%$, $25 \%$ o, $30 \%$, $35 \%$ o, or $40 \%$ o) in each well of 24-well plates. The culture plates were incubated at $25^{\circ} \mathrm{C}$. Zoospore release rates were measured as described above.

Experiments were carried out in triplicates for both temperature and salinity.

\section{Results}

Effects of temperature and salinity on trophozoite proliferation

We repeated identical trials twice, and described below the trends observed commonly in the two trials.

Temperature. The proliferation of both $P$. olseni and $P$. honshuensis was highest at $28^{\circ} \mathrm{C}$ (Fig. $1 \mathrm{~A}$ and B). Although high temperatures had a similar effect on proliferation between the two species, the effects of lower temperatures slightly differed. Both the species proliferated at $34^{\circ} \mathrm{C}$ but did not at $37^{\circ} \mathrm{C}$. However, whereas the proliferation rate of $P$. olseni decreased gradually as temperature declined, that of $P$. honshuensis decreased drastically below $22^{\circ} \mathrm{C}$.

Salinity. The proliferation of $P$. olseni was highest between 600 mOsm (18\%) and 890 mOsm (27\%) (Fig. 1C). Osmolalities outside this range clearly suppressed the proliferation of $P$. olseni. On the other 

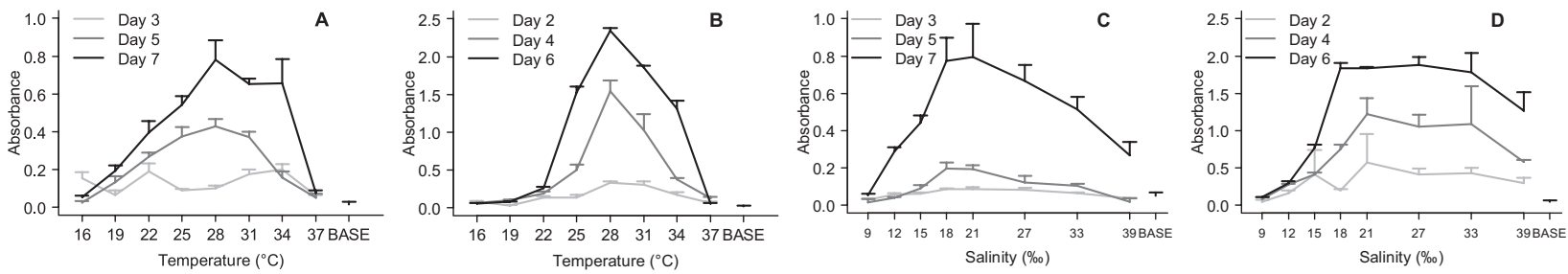

Fig. 1. Effects of incubation temperature $(\mathrm{A}, \mathrm{B})$ and media salinity $(\mathrm{C}, \mathrm{D})$ on in vitro proliferation of $P$. olseni $(\mathrm{A}, \mathrm{C})$ and $P$. honshuensis $(B, D)$. Each point represents the mean of absorbance \pm SD. BASE represents the mean of absorbance \pm SD on day 0 .
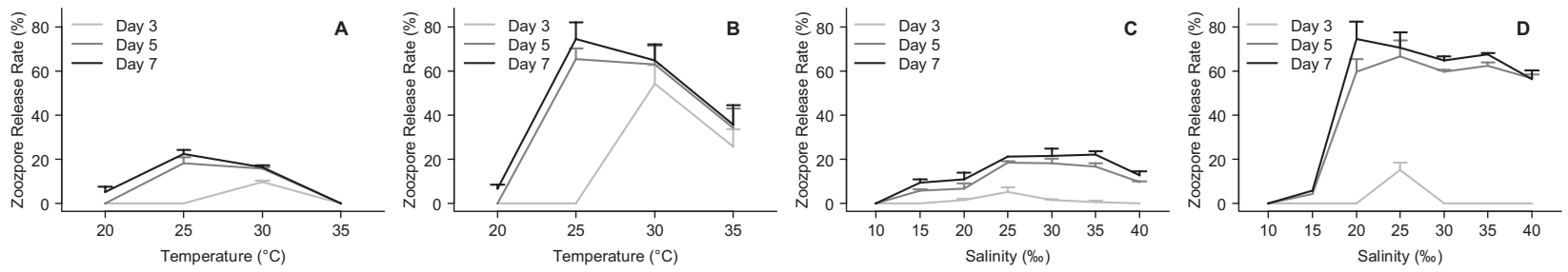

Fig. 2. Effect of temperature $(A, B)$ and salinity $(C, D)$ on zoosporangial development in $P$. olseni $(A, C)$ and $P$. honshuensis $(B, D)$. The points represent the mean of cumulative zoospore release rates at different treatment temperatures and salinities.

hand, the proliferation of $P$. honshuensis was highest within a wider range of osmolalities (700-1,080 mOsm, 21-33\%) (Fig. 1D). For both species, trophozoite proliferation was strongly inhibited at 300 mOsm (9\%).

Effects of temperature and salinity on the development of zoosporangia

Temperature. The cumulative zoospore release rate of $P$. olseni prezoosporangia was highest (15$25 \%$ ) between $25^{\circ} \mathrm{C}$ and $30^{\circ} \mathrm{C}$ on day 7 . At $35^{\circ} \mathrm{C}$, zoosporulation was observed in some prezoosporangia but zoospore release was not (Fig. 2A). For $P$. honshuensis, zoospore release was highest (65-75\%) between $25^{\circ} \mathrm{C}$ and $30^{\circ} \mathrm{C}$ (Fig. 2B), but zoospore release was observed at all temperatures.

Salinity. The zoospore release rate was higher between $25 \%$ and $35 \%$ on day 7 in P. olseni (Fig. 2C). Zoosporulation occurred at a low rate but no zoospore release was observed at $10 \%$. For $P$. honshuensis, zoospore release rate was high $(65-75 \%)$ at $20-35 \%$. Zoospores were released at a low rate $(<10 \%)$ at $15 \%$, but they looked abnormal (i.e. heterogeneity of size and abnormal shape). There was no zoosporulation and zoospore release at 10\%。 (Fig. 2D).

\section{Discussion}

Temperature and salinity conditions play a large role in determining the distribution of aquatic organisms. Thus, understanding the effects of these factors on trophozoite proliferation and zoosporangial development are critical to estimate the potential geographical distribution of Perkinsus species. Our prior research suggests that $P$. olseni was dominant over $P$. honshuensis ${ }^{7,10}$. We hypothesized that temperature and salinity prefer- ences may have played a role in this dominance and in their distribution.

The trophozoites of $P$. olseni and $P$. honshuensis vary considerably in size and frequently exhibit aggregation, thereby rendering conventional cell counting or turbidimetric analysis of little use for measuring cell proliferation. Moreover, viable trophozoites are not distinguishable from nonviable cells. As an alternative, Dungan and Hamilton (1995) successfully used a tetrazolium-based cell proliferation assay to measure the effects of in vitro conditions on $P$. marinus proliferation ${ }^{11)}$. Thus, we used a tetrazolium-based cell proliferation assay kit (CCK-8) to evaluate trophozoite proliferation in $P$. olseni and $P$. honshuensis.

Our results suggest that the effects of temperature on proliferation are similar between these two species, although lower temperatures $\left(<22^{\circ} \mathrm{C}\right)$ appeared to suppress the proliferation of $P$. honshuensis more than $P$. olseni. Proliferation was highest for both species at $28^{\circ} \mathrm{C}$ and both were able to proliferate at temperatures as high as $34^{\circ} \mathrm{C}$, although $37^{\circ} \mathrm{C}$ was lethal for both the species. The development of zoosporangia was highest between $25^{\circ} \mathrm{C}$ and $30^{\circ} \mathrm{C}$ for both the species. The zoospore release rate was significantly lower (TukeyKramer test, $p<0.01$ ) at $35^{\circ} \mathrm{C}$ than at $30^{\circ} \mathrm{C}$ for $P$. honshuensis, and we did not observe zoospore release at $35^{\circ} \mathrm{C}$ for $P$. olseni. We recently measured water temperature ( $5 \mathrm{~cm}$ above the mud surface) and ground temperature (at $5 \mathrm{~cm}$ depth) continuously in a habitat occupied by Manila clams on a tidal flat in the Ariake Sea. Our data suggest that the ground temperature peaked at $35^{\circ} \mathrm{C}$ during summer and declined to $5^{\circ} \mathrm{C}$ during winter (data not shown). The highest and lowest temperatures coincided with low tides when the sediment was exposed to air, and did not continue all day 
long. In the present study, trophozoites of both species proliferated even at $34^{\circ} \mathrm{C}$. Thus, in Manila clams on tidal flats, both species are likely to be able to survive even in summer.

$P$. olseni and $P$. honshuensis were able to proliferate within the range of 400-1,270 mOsm (12-39\%o). Given the salinities at which Manila clams can survive $(\geq 15 \% \circ)^{12)}$, trophozoite proliferation and zoospore release can likely occur in both species in the majority of Manila clam beds. Trophozoite proliferation was highest at 600-890 mOsm (18-27\%) and 700-1,080 mOsm (21-33\%) for $P$. olseni and $P$. honshuensis, respectively. The zoospore release rates were highest between $25 \%$ and $35 \%$ and were suppressed at levels $\leq 15 \%$ ofor both $P$. olseni and $P$. honshuensis. Temperature and salinity ranges optimum for the development of $P$. olseni ( $=P$. atlanticus) have been previously reported: roughly $20-30^{\circ} \mathrm{C}$ and $25-35 \% 0^{13,14)}$. Our present results were not inconsistent with the previous observations.

The infection prevalences and intensities of $P$. olseni were much higher than those of $P$. honshuensis in all Manila clam populations that we previously examined for Perkinsus infection ${ }^{10)}$. Furthermore, Hamaguchi et al. (2002) demonstrated that prevalences of Perkinsus sp. were generally lower in estuarine tidal flats than in non-estuarine tidal flats, suggesting that lower salinities suppress the infection of the parasite ${ }^{4}$. However, either temperature or salinity appears not to limit the proliferation and zoospore release of these two species at the majority of Manila clam beds, based on the present results. We remain unable to explain the observed differences in infection levels between the two species and those between the types of tidal flats demonstrated by Hamaguchi et al. (2002). Lowered oxygen, acidic $\mathrm{pH}$, and increased nutrient levels induced trophozoite differentiation into hypnospore (= prezoosporangium) in $P$. chesapeaki and $P$. olseni in a previous report $^{15)}$. Such factors may influence the production of prezoosporangium and zoospore release for $P$. olseni and $P$. honshuensis, which may result in their difference in infection levels. Furthermore, we have yet to identify the environmental factors affecting the infection level in different areas. To determine why $P$. olseni are dominant over $P$. honshuensis, other factors, such as specific defenses against Perkinsus species and hostparasite interactions, should also be considered. In addition, we suggest that more rigorous monitoring of the physical environment throughout the range of Manila clams might yield insight into the factors contributing to difference in infection level. The effects of environmental conditions on other developmental stages, including the transformation from trophozoites to prezoosporangia, and the survival of zoospore should also be evaluated.

\section{Acknowledgement}

This work was supported by JSPS KAKENHI Grant Number 22380105 and 21658069.

\section{References}

1) Matsukawa, Y., N. Cho, S. Katayama and K. Kamio (2008): Bull. Jpn. Soc. Sci. Fish., 74, 137-143. 2) Shimokawa, J., T. Yoshinaga and K. Ogawa (2010): J. Invert. Pathol., 105, 347-351. 3) Waki, T., J. Shimokawa, S. Watanabe, T. Yoshinaga and K. Ogawa (2012): J. Invert. Pathol., 111, 50-55. 4) Hamaguchi, M., M. Sasaki and H. Usuki (2002): Jpn. J. Benthol., 57, 168-176. 5) Nishihara, Y. (2010): Sci. Rep. Hokkaido Fish. Exp. Stn., 77, 83-88. 6) Dungan, C. F. and K. S. Reece (2006): J. Eukaryot. Microbiol., 53, 316-326. 7) Takahashi, M., T. Yoshinaga, T. Waki, J. Shimokawa and K. Ogawa (2009): Fish Pathol., 44, 185-188. 8) Ray, S. M. (1952): Science, 116, 360-361. 9) Ray, S. M. (1966): Proc. Natl. Shellfish Assoc., 54, 55-69. 10) Umeda, K. and T. Yoshinaga (2012): Dis. Aquat. Org., 99, 215-225. 11) Dungan, C. F. and R. M. Hamilton (1995): J. Euk. Microbiol., 42, 379-388. 12) Matsuda, M., A. Shinagawa, J. Higano, A. Fujii, K. Hirano and A. Ishimatsu (2008): Aquaculture Sci., 56, 127-136. 13) Casas, S. M., A. Villalba and K. S. Reece (2002): Dis. Aquat. Org., 50, 51-65. 14) Ahn, K. J. and K. H. Kim (2001): Dis. Aquat. Org., 48, 43-46. 15) Casas, S. M. and J. F. La Peyre (2012): Eur. J. Protist., (in press) 